\title{
CRITICAL PERIOD OF MUNGBEAN (PHASEOLUS RADIATUS L.) TO WEED COMPETITION
}

\author{
I.H. UTOMO* \\ Tropical Agricultural Pest Biology Program, BIOTROP, Bogor, Indonesia
}

\begin{abstract}
A field experiment was conducted to study the critical period of weed control on the crop of mungbean (Phaseolus radiatus L.). The studies were done in the field of BIOTROP Experimental Station with the natural existing weed population. It was found that the critical period of mungbean to weed competition was from 3-6 weeks after planting.
\end{abstract}

\section{INTRODUCTION}

Competition constitutes the major noxious aspect of weeds in crop cultivation. Since weeds and crops largerly use the same resources for their growth, they will compete when these resources are limited (Zimdahl 1980).

Part of these resources is continuously available in limited amounts, for instance light, or in some extent, nutrient that becomes available by mineralization. Part of these resources, however, is only available as a limited stock at a certain period during crop development.

Environmental factors determine competition by changing space conditions and by affecting the phenotypes of the crops and the weed concerned. When weeds emerge in a newly establishing crop, the amount of resources already utilized by the weeds or crop before competition starts is determined by their seed weight, time of emergence, relative growth rate and population density.

A newly emerged crop seedling relying for food stored in the seed would experience little competition from weed seedlings at a similar growth stage, if only because at that time total demands on water and minerals are small. Likewise a crop towards the end of its growth cycle, especially if it is senescing and ripening seed will often be unharmed by the presence of weeds. Between these situations, there would be a period when crops are most susceptible and weed competition would be more severe. This period is known as the critical period for weed competition. This experiment was aimed at studying the critical period of an annual crop, mungbean (Phaseolus radiatus L.) as basic information on when to control the weeds in such mungbean cultivation.

\footnotetext{
* Present Address: Department of Agronomy, Faculty of Agriculture, Bogor Agricultural University, Bogor, Indonesia.
} 


\section{MATERIALS AND METHOD}

The experiment was conducted at BIOTROP Field Experiment, Tajur, Bogor from July - September 1985. The seed of mungbean (var. PR 74) was planted after land preparation in 30 plots $\left(3 \times 4 \mathrm{~m}^{2}\right)$, fertilized with $50 \mathrm{~kg}$ urea/ha, $100 \mathrm{~kg} \mathrm{TSP} / \mathrm{ha}$ and KCL $50 \mathrm{~kg} / \mathrm{ha}$.

The experiment was arranged in a randomized block design with 3 replications. The treatments of the experiment were as follows (Figure 1)

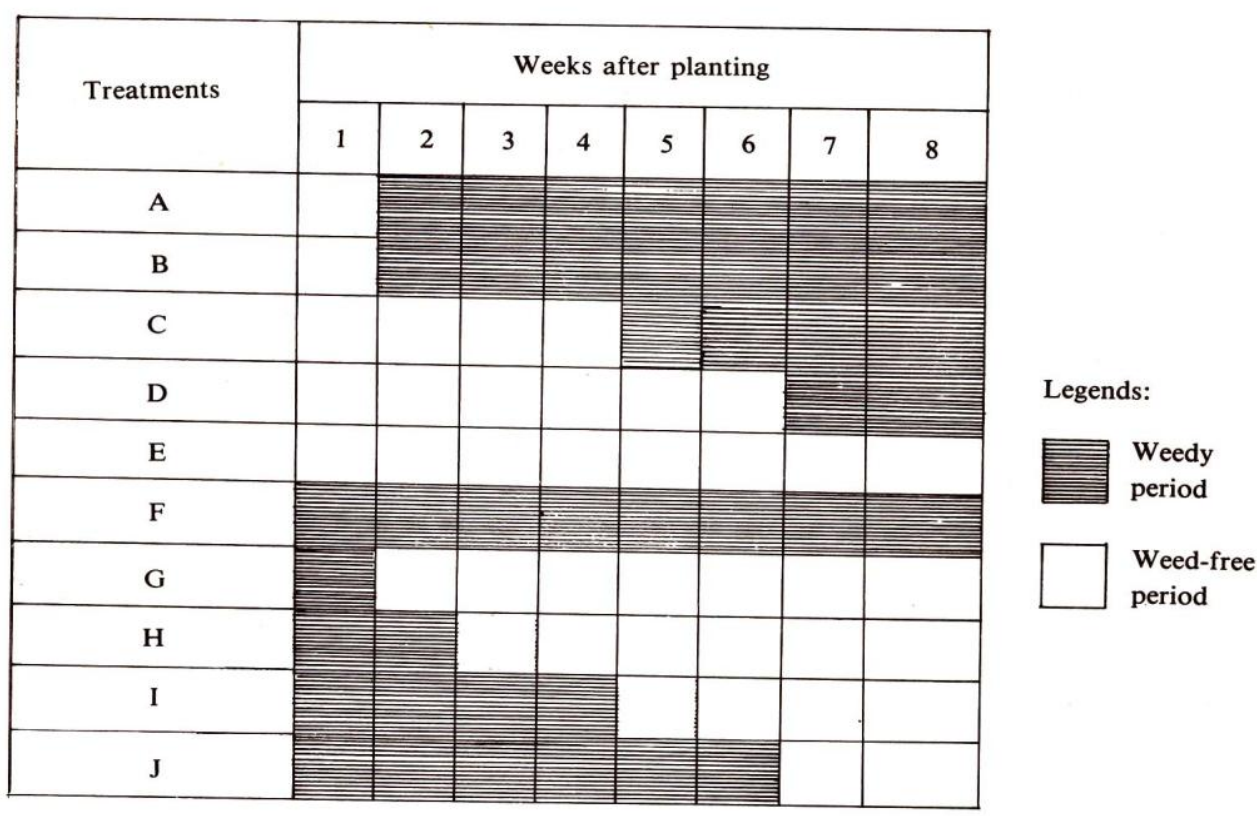

Figure 1. The treatment of the experiment

The serial of periods consisting of weed-free and weedy conditions were introduced at 1, 2, 4, 6 and 8 weeks after planting.

The growth and yield performance parameters of mungbean were recorded as follows:

(1) biomass at 2, 4, 6 and 8 weeks after planting

(2) plant height at 2, 4,6 and 8 weeks after planting

(3) yield of mungbean, expressed as dry weight of seed $\left(\mathrm{g} / \mathrm{m}^{2}\right)$. 


\section{RESULTS AND DISCUSSION}

The highest yield of mungbean was obtained with treatment $G$ (weed present only 1 WAP) which was not significantly different with treatment $E$ which was weed-free during the entire mungbean growth period. Weed competition which commenced during the first week was not considered severe (Table 1).

Table 1. Yield of Mungbean.

\begin{tabular}{cl}
\hline \hline Treatment & $\left.\mathrm{g} / \mathrm{m}^{2} *\right)$ \\
\hline A & $63.75 \mathrm{de}$ \\
B & $75.84 \mathrm{cde}$ \\
C & $106.74 \mathrm{ab}$ \\
D & $95.60 \mathrm{bc}$ \\
E & $112.11 \mathrm{ab}$ \\
F & $51.16 \mathrm{e}$ \\
O & $125.84 \mathrm{a}$ \\
H & $88.42 \mathrm{bcd}$ \\
I & $98.77 \mathrm{bc}$ \\
J & $61.58 \mathrm{e}$ \\
\hline
\end{tabular}

*) Means followed by the same letter are not significantly different at $\mathrm{P} \leq 0.05$.

Data in Table 1 show that mungbean yield decreased from 112.11 to $51.16 \mathrm{~g} / \mathrm{m}^{2}$ when weeds were allowed to grow unchecked throughout the growing period.

The competition effect of weed was evident at each stage of the growing period and the longer weed was present in the cultivation, the lower yield of mungbean. The same results were also observed in relation to the duration of weeding application, i.e. the longer the duration of weeding application, the higher the yield of crop.

The highest yield $(\mathrm{G})$ was not significantly different from treatments C, D, E (for respective weed-free treatments) and $\mathrm{H}$, I (for respective weedy treatments). The grain yield of mungbean therefore started to decrease if weeds occurred in crop cultivation before 6 weeks after planting. Thus, 4 weeks after planting is the indicated time for weeding so that the crop will produce yield comparable to plots free of weed throughout the growing period.

The period of weeding time seemed not to influence the other measurements like biomass (except at 6 WAP) and plant height of mungbean (Table 2). 
Table 2. Plant height and biomass of mungbean.

\begin{tabular}{ccccccl}
\hline \hline \multirow{2}{*}{ Treatments } & \multicolumn{3}{c}{ Plant height (cm) } & \multicolumn{3}{c}{ Biomass of mungbean } \\
\cline { 2 - 7 } & $\left.2{ }^{*}\right)$ & 4 & 6 & 2 & 4 & 6 \\
\hline A & $\left.7.4 \mathrm{a}^{* *}\right)$ & $10.8 \mathrm{a}$ & $24.3 \mathrm{a}$ & $1.54 \mathrm{a}$ & $9.98 \mathrm{a}$ & $68.72 \mathrm{~cd}$ \\
$\mathrm{~B}$ & $7.3 \mathrm{a}$ & $11.1 \mathrm{a}$ & $29.2 \mathrm{a}$ & $1.35 \mathrm{a}$ & $12.10 \mathrm{a}$ & $69.93 \mathrm{bcd}$ \\
$\mathrm{C}$ & $7.8 \mathrm{a}$ & $10.8 \mathrm{a}$ & $26.7 \mathrm{a}$ & $1.29 \mathrm{a}$ & $13.35 \mathrm{a}$ & $84.57 \mathrm{a}$ \\
$\mathrm{D}$ & $7.0 \mathrm{a}$ & $10.3 \mathrm{a}$ & $25.9 \mathrm{a}$ & $1.49 \mathrm{a}$ & $13.67 \mathrm{a}$ & $73.62 \mathrm{abcd}$ \\
$\mathrm{E}$ & $7.6 \mathrm{a}$ & $11.1 \mathrm{a}$ & $27.2 \mathrm{a}$ & $1.30 \mathrm{a}$ & $11.06 \mathrm{a}$ & $79.22 \mathrm{abc}$ \\
$\mathrm{F}$ & $7.3 \mathrm{a}$ & $10.3 \mathrm{a}$ & $23.8 \mathrm{a}$ & $1.42 \mathrm{a}$ & $9.55 \mathrm{a}$ & $51.69 \mathrm{e}$ \\
$\mathrm{G}$ & $7.2 \mathrm{a}$ & $10.5 \mathrm{a}$ & $24.7 \mathrm{a}$ & $1.39 \mathrm{a}$ & $11.73 \mathrm{a}$ & $52.92 \mathrm{e}$ \\
$\mathrm{H}$ & $7.9 \mathrm{a}$ & $10.8 \mathrm{a}$ & $26.2 \mathrm{a}$ & $1.49 \mathrm{a}$ & $13.37 \mathrm{a}$ & $62.26 \mathrm{de}$ \\
$\mathrm{I}$ & $7.1 \mathrm{a}$ & $10.3 \mathrm{a}$ & $25.2 \mathrm{a}$ & $1.27 \mathrm{a}$ & $11.29 \mathrm{a}$ & $61.95 \mathrm{e}$ \\
$\mathrm{J}$ & $7.7 \mathrm{a}$ & $11.6 \mathrm{a}$ & $27.2 \mathrm{a}$ & $1.57 \mathrm{a}$ & $10.66 \mathrm{a}$ & $61.87 \mathrm{a}$ \\
\hline
\end{tabular}

*) 2, 4, 6: indicating the time of treatment in weeds after planting.

**) Means followed by the same letter are not significantly different at $P \leqslant 0.05$

\section{REFERENCES}

NIETO,J.H., M.A. BRONDOand J.T. GONZALES. 1968. Critical periods of the growth cycle for competition from weeds. PANS (c) 14: 159-166.

ZIMDAHL, L. 1979. Crop-weeds competition. International Plant Protection Centre. 